\title{
Uptake and transport of nitrogen derived from sessile epifauna in the giant kelp Macrocystis pyrifera
}

\author{
Christopher D. Hepburn ${ }^{1,3}$, Russell D. Frew ${ }^{2}$, Catriona L. Hurd ${ }^{1}$ \\ Department of Botany ${ }^{1}$, and Department of Chemistry ${ }^{2}$, University of Otago, PO Box 56, Dunedin 9054, New Zealand \\ ${ }^{3}$ Present address: Department of Marine Science, University of Otago, PO Box 56, Dunedin 9054, New Zealand
}

\begin{abstract}
Sessile epifauna that excrete ammonium as a waste product are often closely associated with surfaces of macroalgae that are able to absorb and use ammonium for growth. This close association means that nitrogen provisioning from epifauna to host macroalgae is probable, but barriers to uptake, formed by epifaunal colonies, and the physiological status of colonised macroalgal tissue may limit the amount of ammonium absorbed by colonised macroalgae. Evidence for the movement of nitrogen from sessile epifauna into and around the giant kelp Macrocystis pyrifera was gathered using a ${ }^{15} \mathrm{~N}$-enriched stable isotope tracer. Experiments in which ${ }^{15} \mathrm{~N}$-labelled phytoplankton was fed to the epifaunal bryozoan Membranipora membranacea did not to find conclusive evidence for the flow of nitrogen released by bryozoan colonies into colonised $M$. pyrifera tissue. The low degree of transmission of ${ }^{15} \mathrm{~N}$ observed may be due to the barrier to nitrogen uptake that is formed by $M$. membranacea tissue and the low affinity for ammonium uptake by $M$. pyrifera blades during winter. $M$. membranacea is unlikely to provide significant benefits to host macroalgae via nitrogen provision in many situations, due to its sheet-forming habit and its absence during summer low-nitrogen periods. In situ incubations of $M$. pyrifera blades in ${ }^{15} \mathrm{~N}$-enriched ammonium were used to determine if ammonium provided by epifaunal colonies could be taken up by mature blades tissue and exported to the stipe for long-distance transport to actively growing meristems. Uptake and export of labelled nitrogen from basal blades into the stipe was measured, and the potential for longdistance transport of nitrogen from older blades was confirmed. Active transport of nitrogen from older macroalgal tissue colonised by epifauna such as hydroids could be an important mechanism allowing kelp with specialised long-distance solute transport systems to tolerate nitrogen limitation.
\end{abstract}

KEY WORDS: Ammonium excretion - Bryozoans - Epifauna $\cdot$ Kelp $\cdot$ Long-distance transport · Membranipora membranacea $\cdot$ Macrocystis pyrifera $\cdot$ Nitrogen $\cdot$ Stable isotope tracers $\cdot{ }^{15} \mathrm{~N}$

\section{INTRODUCTION}

Nitrogen is the major limiting nutrient for macroalgal primary productivity (Hanisak 1983) and therefore is an important factor in the functioning of coastal ecosystems that rely on this productivity (Duggins et al. 1989). Mobile and sessile fauna that live on macroalgal surfaces may reduce the effects of nitrogen limitation via their excretion of ammonium (Gerard \& Mann 1979, Probyn \& Chapman 1983, Hurd et al. 1994, Taylor \& Rees 1998, Hepburn \& Hurd 2005, Fram et al. 2008). The cheilostomate bryozoan Membranipora membranacea is a key epifaunal species on macroalgal surfaces in both northern and southern hemispheres (Dixon et al. 1981, Seed \& O'Conner 1981, Harvell 1986, Berman et al. 
1992, Lambert et al. 1992, Schwaninger 1999, Hepburn \& Hurd 2005, Saunders \& Metaxas 2008). Through the capture and digestion of food items (e.g. phytoplankton, detritus, dissolved organic matter; Ryland 1970, Winston 1977, De Burgh \& Fankboner 1978), suspension feeding by $M$. membranacea colonies may make nitrogen bound within particulate matter in the water column available to its kelp substratum in the form of ammonium.

Membranipora membranacea is able to absorb exudates from macroalgal surfaces as a supplement to food it captures through suspension feeding (De Burgh \& Fankboner 1978, Manríquez \& Cancino 1996). In turn, ammonium diffuses rapidly from $M$. membranacea due to its high solubility and low molecular size. It has been proposed that some waste ammonium from $M$. membranacea is excreted through its base, which is in direct contact with the seaweed surface (Hurd et al. 1994). This pathway has been proposed as a basis for a mutualistic relationship between this bryozoan and the giant kelp Macrocystis pyrifera (Hurd et al. 1994) and could provide enhanced productivity of important kelp forest habitats over the wide geographic distribution of both partners (e.g. Schwaninger 1999, Steneck et al. 2002).

The hypothesis that Membranipora membranacea provides nitrogen to underlying Macrocystis pyrifera blade tissue was founded on the observation that M. pyrifera blade tissue beneath bryozoan colonies had higher nitrogen content when compared to surrounding bryozoan-free blade tissue (Hurd et al. 1994). However, flow of nitrogen from M. membranacea into colonised blade tissue has never been demonstrated. Feeding experiments utilising phytoplankton enriched with the stable isotope ${ }^{15} \mathrm{~N}$ as food items were designed to determine if significant amounts of ammonium released by $M$. membranacea colonies during the feeding process (e.g. rupture of cells) and the production of waste products following digestion were taken up by underlying $M$. pyrifera blade tissue. The addition of ${ }^{15} \mathrm{~N}$ labelled phytoplankton was predicted to enrich $M$. pyrifera blade tissue colonised by $M$. membranacea with ${ }^{15} \mathrm{~N}$ but not bryozoan-free blade tissue as the process of feeding and digestion of phytoplankton by the bryozoan colony would be required to release labelled nitrogen stored within phytoplankton cells to make it available for uptake by blade tissue.

This study also aimed to identify if nitrogen excreted by sessile epifauna, such as bryozoans and other important epifaunal groups (e.g. hydroids) that are most common at the base of Macrocystis pyrifera fronds (Hepburn \& Hurd 2005) can be made avail- able to distant meristems at frond apices. Growth and nitrogen status of apical sections of $M$. pyrifera fronds have been demonstrated to increase with increasing cover of hydroids found on basal blades that were many metres distant from growing apices (Hepburn \& Hurd 2005). Transport of nitrogen derived from epifauna growing on basal blades to distant meristems is possible through specialised cells found in the stipes of kelp (Raven 2003). These cells resemble the sieve tube elements of higher plants, and are able to transport carbon, mainly as mannitol, and probably nitrogen (as amino acids and protein) rapidly along the frond (Parker 1963, 1965, Lobban 1978, Schmitz \& Srivastava 1979a, Manley 1983). Due to environmental (Gerard 1984) and physiological reasons (Kain 1982) it is estimated that the majority of $M$. pyrifera production occurs in the canopy region (Towle \& Pearse 1973, Gerard 1984) and that basal blades that are senescent have limited roles in light harvesting. It is possible that basal blades that are heavily colonised by sessile epifauna could have a significant role in providing nitrogen to the apical and basal meristems of $M$. pyrifera if nitrogen uptake and transport capacity remains in mature blade tissue, despite apparent senescence and disintegration (Hepburn \& Hurd 2005).

\section{MATERIALS AND METHODS}

Collection of Macrocystis pyrifera blade tissue for feeding experiments took place at Harington Point at the entrance to Otago Harbour, South Island, New Zealand (454 $7^{\prime} 03.5^{\prime \prime}$ S, $170^{\circ} 43^{\prime} 22.7^{\prime \prime}$ E). In situ nitrogen transport experiments were conducted at a kelp bed at Omimi Cove ( $\left.45^{\circ} 41^{\prime} 29.0^{\prime \prime} \mathrm{S}, 170^{\circ} 37^{\prime} 0.0^{\prime \prime} \mathrm{E}\right)$, a sheltered bay $13 \mathrm{~km}$ northwest of Harington Point. This area was chosen due to the lack of strong tidal currents that would have made carrying out this experiment at Harington Point difficult.

\section{Laboratory feeding experiments}

Dunaliella tertiolecta was selected as food for Membranipora membranacea in feeding experiments as it is an excellent food source for bryozoan colonies (Winston 1977). D. tertiolecta (innoculant from Portobello Marine Laboratory, University of Otago) was cultured in 11 Erlenmeyer flasks in a culture medium made up with seawater filtered using Whatman GF/C filters ( $1 \mu \mathrm{m})$ and sterilized in an autoclave, and f/2 medium (Guillard \& Ryther 1962) with $20 \mu \mathrm{M}$ 
$10.4 \%{ }^{15} \mathrm{~N}$-enriched $\left(\mathrm{NH}_{4}\right)_{2} \mathrm{SO}_{4}$ (Novachem) as the nitrogen source.

Culture greater than 3 wk old were used for feeding experiments as it was assumed that most ${ }^{15} \mathrm{~N}$ labelled ammonium would by then have been absorbed into phytoplankton biomass. Three litres of ${ }^{15} \mathrm{~N}$-enriched phytoplankton cultures were centrifuged in $500 \mathrm{ml}$ centrifuge tubes at $1000 \mathrm{rpm}$ for 5 min after which the supernatant was decanted off. The remaining phytoplankton mixture was centrifuged again for $5 \mathrm{~min}$ at $1000 \mathrm{rpm}$ before the supernatant was decanted once more. This left $40 \mathrm{ml}$ of highly concentrated phytoplankton for use in feeding experiments. Observations of phytoplankton through a microscope before and after centrifugation showed no evidence of a reduction in the numbers of motile phytoplankton as a result of this process. The concentrated phytoplankton solution was then placed in an incubator (Conviron Model E15) at $12^{\circ} \mathrm{C}$ for $2 \mathrm{~h}$ to acclimatize to experimental conditions.

Ten mature blades from the basal sections of separate Macrocystis pyrifera individuals that were colonised by Membranipora membranacea were haphazardly collected by SCUBA from 2 to $4 \mathrm{~m}$ depth at Harington Point during the austral winter on 6 July 2001, the day before experiments took place. The blades were covered in newspaper (that had been soaked in seawater) within covered bins for immediate transport to the laboratory $1 \mathrm{~h}$ away where they were placed in aerated seawater. To prevent damage to attached $M$. membranacea colonies, sections of bryozoan colonised blade tissue were cut from the blade around the colonies edge using a razor blade (bryozoan-colonised group). A second, identically shaped section of blade tissue was then cut from adjacent blade tissue (bryozoan-free group). Blade sections from the same blade remained paired for subsequent experiments. Blade sections were then placed in filtered seawater, in an incubator for $2 \mathrm{~h}$ at $12^{\circ} \mathrm{C}$ in the dark. Tissue discs were then placed in separate $100 \mathrm{ml} 10 \% \mathrm{HCl}$-washed flasks containing $50 \mathrm{ml}$ of low ammonium $(<1 \mu \mathrm{M})$ filtered seawater. Flasks were placed randomly on gently moving orbital shaker tables (Model SS70, Chiltern Scientific) in the incubator for $12 \mathrm{~h}$ at $12^{\circ} \mathrm{C}$ in the dark to facilitate acclimation by $M$. membranacea colonies and $M$. pyrifera blade tissue. An irradiance of $260 \mu \mathrm{mol} \mathrm{m} \mathrm{m}^{-2} \mathrm{~s}^{-1}$ was provided by 8 daylight fluorescent tubes (F72T12-CW-VHO, Sylvania) for $2 \mathrm{~h}$ before and throughout feeding experiments. Temperature and light levels were typical of those observed in shallow water habitats in southern New Zealand (Kregting et al. 2008, Hepburn et al. 2011).
Two treatment groups and 2 control groups of paired bryozoan-colonised and bryozoan-free blade tissue were used $(\mathrm{n}=5)$. One $\mathrm{ml}$ of concentrated phytoplankton food was added to each treatment group, while no phytoplankton was added to control groups. All colonies were observed to be actively feeding during the incubation. Both control and treatment flasks were left in the incubator on orbital shaker tables set at $120 \mathrm{rpm}$ for $8 \mathrm{~h}$. Blade sections were then removed and washed in purified water. Bryozoan colonies were scraped off the blade tissue discs and dried in plastic tubes at $80^{\circ} \mathrm{C}$. Blade sections were washed in purified water and all bryozoan tissue was removed before drying. Blade and bryozoan tissue were ground in a mortar and pestle before storage in sealed tubes prior to analysis for $\delta^{15} \mathrm{~N}$. A separate mortar and pestle was used for the controls and ${ }^{15} \mathrm{~N}$-enriched blade and bryozoan tissue to prevent contamination.

\section{In situ nitrogen transport in Macrocystis pyrifera fronds}

To determine if ammonium, taken up by older blade tissue, could be exported from colonised blades and then transported along the stipe, ${ }^{15} \mathrm{~N}$ enriched nitrogen was traced from the site of uptake by blades near the base of fronds of Macrocystis pyrifera and along the stipe to apical and basal meristems in situ. Transport of ammonium-derived nitrogen in $M$. pyrifera fronds was measured during the austral summer of 2000 (December) using a method modified from Lobban (1978). Three $M$. pyrifera individuals were selected from a kelp bed with bottom depths of 3 to $5 \mathrm{~m}$. A $4 \mathrm{~h}$ experimental incubation period was considered sufficient based on studies that have observed the transport of radioactive ${ }^{14} \mathrm{C}$ and ${ }^{32} \mathrm{P}$ from mature blades and along the entire frond of $M$. integrifolia within $4 \mathrm{~h}$ (Schmitz \& Srivastava 1979a,b).

A blade was selected from each of the 3 Macrocystis pyrifera individuals that was situated between 30 and 40 blades ( 1.5 to $1.8 \mathrm{~m}$ ) from the apical meristem (Fig. 1). Blades from this section of the frond are typically colonised by Membranipora membranacea and other epifaunal species (Hepburn \& Hurd 2005), but during the experiment, epifaunal cover was low and covered less than $5 \%$ of blades selected. One 81 clear, polyethelene bag was sealed around selected blades with flagging tape at the base and top of the pneumatocyst, using SCUBA. In preliminary experiments, universal dye was added to the sealed bag 


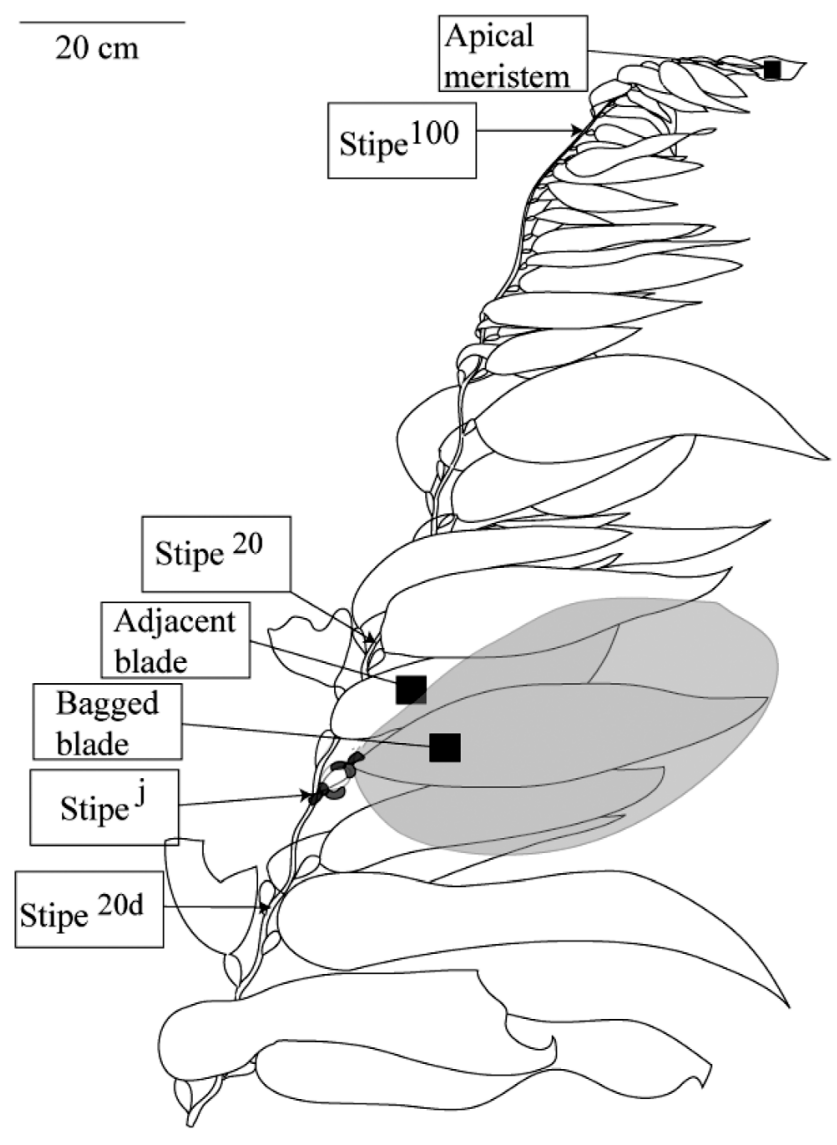

Fig. 1. Macrocystis pyrifera. Sampling plan of kelp fronds used for the in situ nitrogen transport experiment. Superscript numbers of stipe sample denote the distance $(\mathrm{cm})$ from the bagged (grey shading) blade/stipe junction (Stipej) to the sample. Stipe ${ }^{20 d}$ indicates a stipe sample from $20 \mathrm{~cm}$ down the frond towards the holdfast.

and revealed no leakage of fluid contained within the bags. Each bag contained a screw-top bottle containing $20 \mathrm{ml}$ of $6.25 \mathrm{mM}\left(\mathrm{NH}_{4}\right)_{2} \mathrm{SO}_{4}$ solution enriched by $10.4 \%$ with ${ }^{15} \mathrm{~N}$. Bags were filled with 4.50 to 5.251 of seawater to approx. $75 \%$ of capacity to allow flexibility and water movement within the bag. Once the bag was sealed, the bottle was unscrewed through the side of the plastic bag releasing the ammonium to provide an initial concentration within the bag of approx. $50 \mu \mathrm{M}$ above ambient. The plastic bag was then carefully shaken to mix the ammonium.

After $4 \mathrm{~h}$, entire fronds with the bagged blades were cut at their base along with an adjacent frond from the same Macrocystis pyrifera individual that served as a control. Bags and the blades contained within them were then cut at the base of the pneumatocyst and placed, still sealed, aboard the boat. All cutting of $M$. pyrifera fronds was carried out in the water to prevent contamination on the boat deck.
Samples of blade and stipe tissue along the 3 treatment and control fronds were taken using the sampling plan described in Fig. 1, and samples were placed in separate labelled zip-lock plastic bags. Lengths of stipe measuring approx. $5 \mathrm{~cm}$ were taken for stipe samples, while around $2 \mathrm{~g}$ (wet weight) of tissue was collected for blade and apical meristem samples from treatment and control fronds. After all blade and stipe samples had been collected, the volume of water in the bags was measured and blade tissue samples taken. All samples were then placed in an insulated bin for transport to the laboratory $1.5 \mathrm{~h}$ away. Water samples were taken from seawater surrounding each of the 3 sealed bags at the beginning of the incubation period and from water inside each bag $4 \mathrm{~h}$ later. The percentage of ammonium taken up by bagged $M$. pyrifera blades was estimated using the following:

$$
\% \mathrm{NH}_{4}^{+} \text {taken up }=\left[1-\left(\frac{S_{f}}{S_{a}+50 \mu \mathrm{M}}\right)\right] \times 100
$$

Where, $S_{f}=\mathrm{NH}_{4}{ }^{+}$concentration $(\mu \mathrm{M})$ within the bags following the incubation period; $S_{a}=\mathrm{NH}_{4}{ }^{+}$concentration of seawater surrounding bagged blades (ranged from 2-3 $\mu \mathrm{M}$ ); and $50 \mu \mathrm{M}=$ concentration of ${ }^{15} \mathrm{~N}$ labelled $\mathrm{NH}_{4}{ }^{+}$within bags.

Blade and stipe tissue was then returned to the laboratory where it was dried at $80^{\circ} \mathrm{C}$ and ground using a mortar and pestle along with liquid nitrogen to aid grinding/homogenisation. Care was also taken not to contaminate tissue from parts of the stipe more distant from the bagged blades with more ${ }^{15} \mathrm{~N}$-enriched tissue by grinding samples further from the bagged blades first. Water samples were filtered (GF/C 1 $1 \mu \mathrm{m}$ ) and ammonium concentrations were determined using a Quickchem ${ }^{\circledR} 8000$ automated ion analyser (Lachat Instruments).

Subsamples of dried, ground Macrocystis pyrifera tissue (1-2 mg) were combusted in a Carlo Erba NA1500 Elemental Analyzer (Carlo-Erba) interfaced to a Europa Scientific 20-20 update (SIRA10) continuous flow mass spectrometer (Sercon Australia). Corrections for drift were made automatically from a standard (EDTA, calibrated against NBS standards $\mathrm{N} 1$ and N2) with a known isotopic ratio every 5 samples. Ratios of ${ }^{15} \mathrm{~N}:{ }^{14} \mathrm{~N}$ are expressed in standard $\delta^{15} \mathrm{~N}$ (\%) notation with respect to air.

Differences in $\delta^{15} \mathrm{~N}$ between experimental groups were evaluated using paired $t$-tests $(\alpha=0.05)$. Tests for normality and equal variance were carried out to see if the criteria to perform parametric tests were fulfilled. All statistical analyses were carried out using the software package SigmaStat 2.03 (SPSS). 


\section{RESULTS}

\section{Laboratory feeding experiments}

Treatment Membranipora membranacea tissue samples became enriched with ${ }^{15} \mathrm{~N}$ from the phytoplankton food and displayed $\delta^{15} \mathrm{~N}$ values 26 times higher than control bryozoan tissue (Fig 2). An increase in the $\delta^{15} \mathrm{~N}$ value of $3 \%$ was observed for colonised Macrocystis pyrifera blade tissue from the treatment group compared to treatment bryozoanfree blade tissue but this difference was not significant (paired $t$-test, $t=-0.889, \mathrm{p}=0.424$ ). There was also no significant difference observed between control colonised and bryozoan-free blade tissue groups (paired $t$ - test, $t=0.0869, \mathrm{p}=0.935$ ).

\section{In situ nitrogen transport in Macrocystis pyrifera fronds}

Macrocystis pyrifera blade tissue from within the bags into which ${ }^{15} \mathrm{~N}$-labelled ammonium was released became highly enriched with the ${ }^{15} \mathrm{~N}$ tracer, having $\delta^{15} \mathrm{~N}$ values approx. 220 times higher than control blades from an adjacent frond (Fig. 3). The level of enrichment was, however, quite variable, ranging $250 \%$ between bagged blade values from each replicate frond. The bagged blades absorbed on average $89 \pm 6 \%\left(\mathrm{SE}_{;} \mathrm{n}=3\right)$ of the ammonium available from seawater within the polythene bags. There

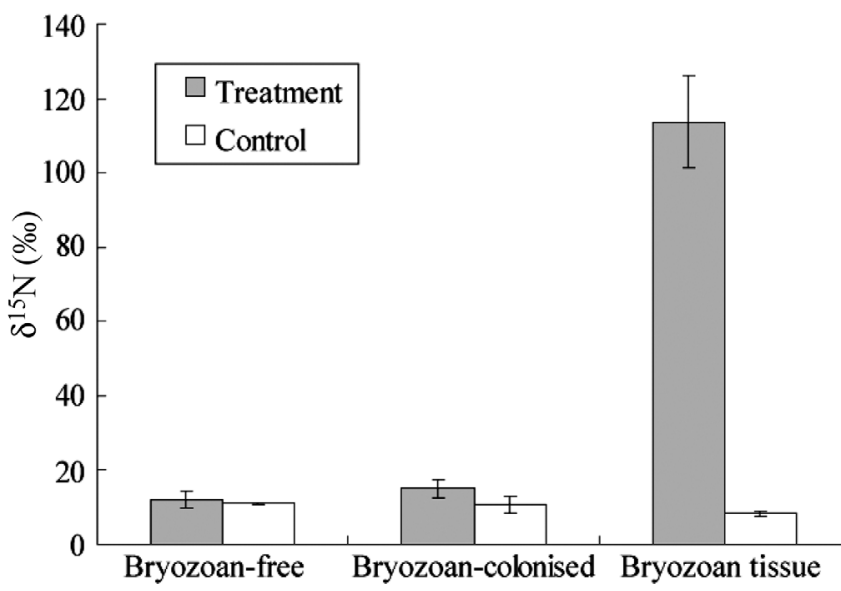

Fig. 2. Macrocystis pyrifera and Membranipora membranacea. $\delta^{15} \mathrm{~N}$ values of kelp blade tissue and that of bryozoan colonies following feeding experiments ( $8 \mathrm{~h}$ duration). Treatment samples had $1 \mathrm{ml}$ of concentrated ${ }^{15} \mathrm{~N}$-enriched Dunaliella tertiolecta added at the beginning of the incubation period while nothing was added for control samples. Values indicate means $\pm 1 \mathrm{SE}(\mathrm{n}=5)$ was evidence that bagged blades exported ammonium to the stipe during the $4 \mathrm{~h}$ incubation period. $\delta^{15} \mathrm{~N}$ values of the treatment stipe tissue at the junction of the bagged blade and the stipe (Stipe ${ }^{\mathrm{J}}$ ) were significantly higher than control blade tissue (paired $t$-test, $t=4.42, \mathrm{p}=0.005) . \delta^{15} \mathrm{~N}$ values were almost 3 times higher in treatment stipe tissue located $20 \mathrm{~cm}$ down the frond towards the holdfast (Stipe ${ }^{20 d}$ ) but this difference was not statistically significant (paired $t$-test, $t=-2.24, \mathrm{p}=0.154)$. There was, however, no evidence of any transport of the ${ }^{15} \mathrm{~N}$ tracer along the stipe towards the frond apex (Stipe ${ }^{100}$ ).

\section{DISCUSSION}

The present study finds no strong evidence for the flow of nitrogen from Membranipora membranacea into underlying Macrocystis pyrifera tissue. The low degree of transmission of ${ }^{15} \mathrm{~N}$ observed was probably due to the barrier formed by $M$. membranacea tissue to nitrogen uptake by underlying blade tissue (Hurd et al. 1994) and the low affinity for uptake of ammo-

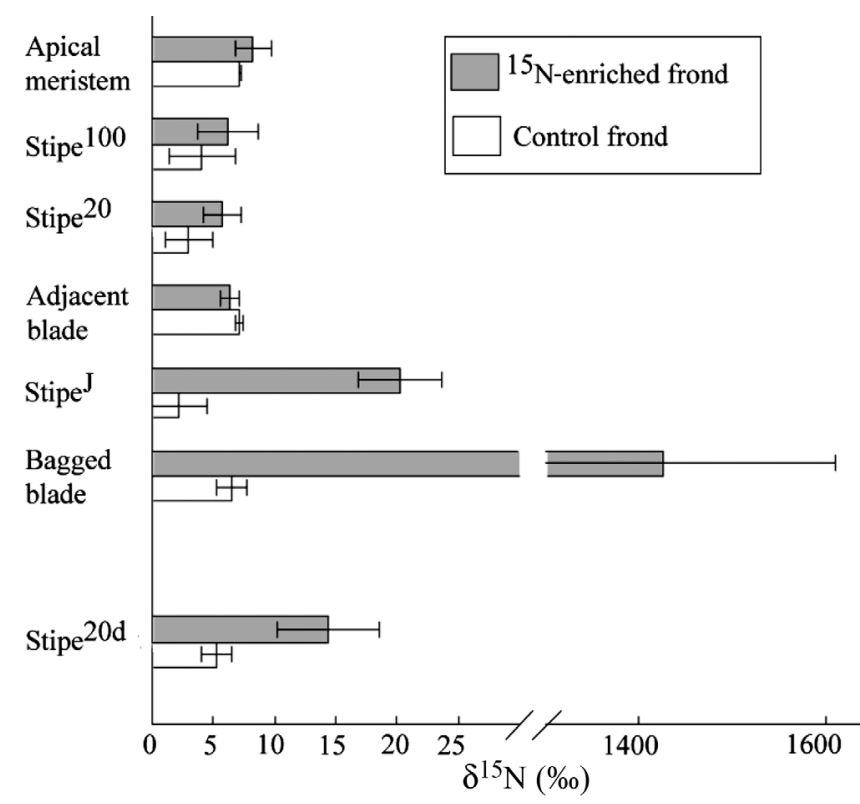

Fig. 3. Macrocystis pyrifera. $\delta^{15} \mathrm{~N}$ values of stipe and blade tissue from kelp fronds used to trace uptake and transport of nitrogen derived from ammonium in situ. Ten percent ${ }^{15} \mathrm{~N}$-enriched ammonium was made available to treatment fronds via a sealed bag that surrounded the bagged blade. Control frond tissue was taken from the same positions on an adjacent frond from the same individual. See Fig. 1 for position of samples. Values represent means $\pm 1 \mathrm{SE}(\mathrm{n}=3)$. Superscript numbers of stipe sample denote the distance (cm) from the bagged blade/stipe junction (Stipe ${ }^{\mathrm{j}}$ ) to the sample 
nium during the winter (Hepburn et al. 2006). Ammonium production by $M$. membranacea either as a result of sloppy feeding or due to excretion of waste products occurred on the upper surface of the colony away from the blade surface. Therefore, much of the ammonium produced by bryozoan colonies could be lost to the surrounding water column or to surrounding kelp tissue free from colonisation. The low degree of transmission may also be due to the high nitrogen content of blade tissue (1.6 to $2.2 \%$ ) during this experiment and a corresponding low affinity for ammonium uptake during winter (Hepburn et al. 2006). It is possible that ammonium excretion may actually be harmful to $M$. pyrifera during periods when nitrogen is found in high concentrations. Excess ammonium can be toxic and could be the cause of reduced photopigments (Hepburn et al. 2006) and structural integrity of blade tissue beneath bryozoan colonies in M. pyrifera (Dixon et al. 1981, Hepburn 2003). The absence of $M$. membranacea on M. pyrifera during the summer (Hepburn \& Hurd 2005) prevented a repeat of the experiment in summer, when the nitrogen status of blade tissue is much lower and rates of ammonium uptake can be between 4 and 6 times higher (Hepburn et al. 2006). During periods of low seawater nitrogen, it is likely that provision of nitrogen from M. membranacea to underlying kelp tissue will occur, but the significance of this nitrogen in reducing the effects of nitrogen limitation is yet to be determined.

This study finds further evidence that sheet-forming bryozoans like Membranipora membranacea, which provide a barrier to nitrogen uptake and are not abundant during periods of low nitrogen, are unlikely to provide significant benefits to host macroalgae via nitrogen provision (Hepburn \& Hurd 2005, Hepburn et al. 2006). The timing of colonisation of kelp surfaces by sessile epifauna is critical in deciding the outcome of the relationship between epifauna and the macroalgae they colonise (Hepburn \& Hurd 2005). M. membranacea typically has higher cover on Macrocystis pyrifera blades during the lowlight, high-nitrogen winter months in southern New Zealand (Hepburn \& Hurd 2005). This is consistent with colonisation patterns observed for M. membranacea in Californian kelp beds (Bernstein \& Jung 1979, Yoshioka 1982) and is primarily a result of planktonic factors affecting the ability of the longlived larvae of $M$. membranacea to settle on kelp surfaces (Yoshioka 1982b). During winter, the surface waters are well mixed and $M$. membranacea larvae are concentrated in the upper 5 to $10 \mathrm{~m}$ of the water column, allowing significant colonisation of the surfaces of Macrocystis pyrifera. When the seasonal thermocline forms in the early summer, M. membranacea larvae stop actively swimming and sink below 10 metres to avoid higher surface temperatures (Yoshioka 1982). This results in an inability to colonise shallow water kelp beds during the summer and reduces the probability of $M$. membranacea contributing a significant amount of nitrogen to macroalgal growth during the summer period of nitrogen limitation. Sites that exhibit high levels of colonisation during the summer (Hurd et al. 1994) are likely to be atypical and may be related to entrainment of larvae through localised physical processes (Dixon et al. 1981).

During in situ uptake and transport experiments, mature Macrocystis pyrifera basal blades were able to take up the majority of the ammonium available within the bags over $4 \mathrm{~h}$. The higher affinity for ammonium uptake during in situ experiments was most likely a result of low internal pools of nitrogen within $M$. pyrifera during the summer compared to laboratory experiments that were conducted in winter when internal nitrogen pools are full (Hepburn et al. 2006). Nitrogen transport along the stipe was much slower than that observed for carbon and phosphorus (25 to $45 \mathrm{~cm} \mathrm{~h}^{-1}$, Schmitz \& Srivastava 1979a,b) with rates of $5 \mathrm{~cm} \mathrm{~h}^{-1}$ observed in some individuals and no transport of labelled nitrogen along the stipe away from bagged blades in others. Limited movement of ${ }^{15} \mathrm{~N}$-labelled nitrogen may reflect enzymatic rate limitation of assimilation of ammonium to amino acids and proteins before transport (Parker 1965, Manley 1983), or the time taken to saturate local nitrogen sinks within the blade before export of nitrogen to more distant sinks in apical and basal meristems can occur. Once reaching the stipe there was evidence of transport down the stipe towards the holdfast with ${ }^{15} \mathrm{~N}$ enrichment of 4.5 to $17 \%$ being observed in treatment fronds. As the $\delta^{15} \mathrm{~N}$ values of blade tissue from bagged blades were still very high after the experiment, a longer incubation period may have allowed more mobilization of the ${ }^{15} \mathrm{~N}$ tracer and a stronger signal on more apical sections of the frond.

Despite low levels of bryozoan colonisation observed during times of nitrogen limitation in the present study, the process of transporting nitrogen from older blades heavily colonised by epifauna to meristematic regions could be an important process for many associations between macrolgae and epifauna. High levels of Membranipora membranacea colonisation on Macrocystis pyrifera during time of nitrogen limitation and evidence of nitrogen provision to blade tissue has been observed in other geographic regions 
(Hurd et al. 1994), and for other species within southern New Zealand such as Ecklonia radiata and Carpophyllum flexuosum (C. D. Hepburn pers. obs.). In the current study, hydroids were common on $M$. pyrifera during periods of low nitrogen, and had the potential to provide significant amounts of nitrogen to their kelp substratum during limitation (Hepburn \& Hurd 2005). Future work should focus on transport of nitrogen from more diffuse hydroid colonies and how much nitrogen is maintained within diffusion boundary layers that surround kelp blades (Hurd 2000).

Nitrogen provided by sessile epifauna growing on mature blades that exhibit little or no growth can be exported to the stipe. This may provide nitrogen via long-distance transport to actively growing basal and apical meristems of Macrocystis pyrifera during times of nitrogen limitation, though the relative importance of this nitrogen source is not clear. This process may also be important for other macroalgae that transport solutes relatively long distances through symplasmic transport (Raven 2003) and may result in increased productivity of ecologically important kelp species when nitrogen is limiting to growth.

Acknowledgments. We thank the staff and students of the Botany Department and Marine Botany Research Group, especially S. Bell for technical assistance, S. Miller and J. Phillips for assistance with diving. We also acknowledge the constructive input of 4 anonymous reviewers. This research was funded by a University of Otago Postgraduate Scholarship to C.D.H. and a University of Otago Research Grant to C.L.H.

\section{LITERATURE CITED}

Berman J, Harris L, Lambert WJ, Buttrick M, Dufresne M (1992) Recent invasions of the Gulf of Maine: three contrasting ecological histories. Conserv Biol 6:435-441

Bernstein BB, Jung N (1979) Selective pressures and coevolution in a kelp canopy community in southern California. Ecol Monogr 49:335-355

De Burgh ME, Fankboner PV (1978) A nutritional association between the bull kelp Nereocystis luetkeana and its epizoic bryozoan Membranipora membranacea. Oikos 31:69-72

> Dixon J, Schroeter S, Kastendiek J (1981) Effects of the encrusting bryozoan, Membranipora membranacea, on the loss of blades and fronds by the giant kelp Macrocystis pyrifera (Laminariales). J Phycol 17:341-345

Duggins DO, Simenstad CA, Estes JA (1989) Magnification of secondary production by kelp detritus in coastal marine ecosystems. Science 245:170-173

Fram JP, Stewart HL, Brzezinski MA, Gaylord B, Reed DC, Williams SL, MacIntyre S (2008) Physical pathways and utilization of nitrate supply to the giant kelp, Macrocystis pyrifera. Limnol Oceanogr 53:1589-1603

Gerard VA (1984) The light environment in a giant kelp forest: influence of Macrocystis pyrifera on spatial and temporal variability. Mar Biol 84:189-195

Gerard VA, Mann KH (1979) Growth and production of Laminaria longicruris (Phaeophyta) populations exposed to different intensities of water movement. J Phycol 15: 33-41

Guillard RRL, Ryther JH (1962) Studies of marine planktonic diatoms. I. Cyclotella nana Hustedt and Detonula confervacea Cleve. Can J Microbiol 8:229-239

Hanisak MD (1983) The nitrogen relationships of marine macroalgae. In: Carpenter EJ, Capone DG (eds) Nitrogen in the marine environment. Academic Press, New York, NY, p 699-730

Harvell CD (1986) The ecology and evolution of inducible defences in a marine bryozoan: cues, costs and consequences. Am Nat 128:810-823

Hepburn CD (2003) The influence of sessile epifauna on the ecology and physiology of the giant kelp Macrocystis pyrifera (L.) C. Agardh. PhD dissertation. University of Otago, Dunedin

- Hepburn CD, Hurd CL (2005) A conditional mutualism between the giant kelp Macrocystis pyrifera and colonial epifauna. Mar Ecol Prog Ser 302:37-48

Hepburn CD, Hurd CL, Frew RD (2006) Colony structure and seasonal differences in light and nitrogen modify the impact of sessile epifauna on the giant kelp Macrocystis pyrifera (L.) C Agardh. Hydrobiologia 560:373-384

Hepburn CD, Pritchard DW, Cornwall CE, McLeod RJ, Beardall JB, Raven JA, Hurd CL (2011) Diversity of carbon use strategies in macroalgal communities: implications for a high $\mathrm{CO}_{2}$ ocean. Glob Change Biol 17:2488-2497

Hurd CL (2000) Water motion, marine macroalgal physiology, and production. J Phycol 36:453-472

> Hurd CL, Durante KM, Chia FS, Harrison PJ (1994) Effect of bryozoan colonization on inorganic nitrogen acquisition by the kelps Agarum fimbriatum and Macrocystis integrifolia. Mar Biol 121:167-173

Kain JM (1982) Morphology and growth of the giant kelp Macrocystis pyrifera in New Zealand and California. Mar Biol 67:143-157

> Kregting LT, Hepburn CD, Hurd CL, Pilditch CA (2008) Seasonal patterns of growth and nutrient status of the macroalga Adamsiella chauvinii (Rhodophyta) in soft sediment environments. J Exp Mar Biol Ecol 360:94-102

Lambert WJ, Levin PS, Berman J (1992) Changes in the structure of a New England (USA) kelp bed: the effects of an introduced species? Mar Ecol Prog Ser 88:303-307

Lobban CS (1978) Translocation of ${ }^{14} \mathrm{C}$ in Macrocystis pyrifera (giant kelp). Plant Physiol 61:585-589

Manley SL (1983) Composition of sieve tube sap from Macrocystis pyrifera (Phaeophyta) with an emphasis on inorganic constituents. J Phycol 19:118-121

> Manríquez PH Cancino JM (1996) Bryozoan-macroalgal interactions: Do epibionts benefit? Mar Ecol Prog Ser 138:189-197

> Parker BC (1963) Translocation in the giant kelp Macrocystis. Science 140:891-892

Parker BC (1965) Translocation in the giant kelp Macrocystis I. Rates, direction, Quality of $\mathrm{C}^{14}$-labelled products and fluorescein. J Phycol 1:41-46

> Probyn TA, Chapman ARO (1983) Summer growth of Chordaria flagelliformis (O.F Muell) C. Ag.: Physiological strategies in a nutrient stressed environment. J Exp Mar Biol Ecol 73:243-271

Raven JA (2003) Long-distance transport in non-vascular plants. Plant Cell Environ 26:73-85 
Ryland JS (1970) Bryozoans. Hutchinson \& Co, London

Saunders M, Metaxas A (2008) High recruitment of the introduced bryozoan Membranipora membranacea is associated with kelp bed defoliation in Nova Scotia, Canada. Mar Ecol Prog Ser 369:139-151

Schmitz K, Srivastava LM (1979a) Long distance transport in Macrocystis integrifolia. I. Translocation of ${ }^{14} \mathrm{C}$-labeled assimilates. Plant Physiol 63:995-1002

Schmitz K, Srivastava LM (1979b) Long distance transport in Macrocystis integrifolia. II. Tracer experiments with ${ }^{14} \mathrm{C}$ and ${ }^{32}$ P. Plant Physiol 63:1003-1009

Schwaninger HR (1999) Population structure of the widely dispersing marine bryozoan Membranipora membranacea (Cheilostomata): implications for population history, biogeography, and taxonomy. Mar Biol 135:411-423

Seed R, O'Connor RJ (1981) Community organization in

Editorial responsibility: Christine Paetzold,

Oldendorf/Luhe, Germany marine algal epifaunas. Annu Rev Ecol Syst 12:49-74

Steneck RS, Graham MH, Bourque BJ, Corbett D and others (2002) Kelp forest ecosystems: biodiversity, stability, resilience and future. Environ Conserv 29:436-459

Taylor RB, Rees TAV (1998) Excretory products of mobile epifauna as a nitrogen source for seaweeds. Limnol Oceanogr 43:600-606

Towle DW, Pearse JS (1973) Production of the giant kelp, Macrocystis, estimated by in situ incorporation of ${ }^{14} \mathrm{C}$ in polyethylene bags. Limnol Oceanogr 18:155-159

Winston JE (1977) Feeding in marine bryozoans. In: Woolacott RM, Zimmer RL (eds) Biology of bryozoans. Academic Press, New York, NY, p 233-268

Yoshioka PL (1982) Role of planktonic and benthic factors in the population dynamics of the bryozoan Membranipora membranacea. Ecology 63:457-468

Submitted: December 8, 2010; Accepted: October 5, 2011 Proofs received from author(s): December 6, 2011 